Article

\title{
Ecological Restoration of Compacted Soil Following the Application of Different Leaf Litter Mulches on the Skid Trail over a Five-Year Period
}

\author{
Meghdad Jourgholami ${ }^{1}$ (D), Ali Nasirian ${ }^{1}$ and Eric R. Labelle ${ }^{2, *(D)}$ \\ 1 Department of Forestry and Forest Economics, Faculty of Natural Resources, University of Tehran, \\ Tehran 999067, Iran; mjgholami@ut.ac.ir (M.J.); alinasirian@ut.ac.ir (A.N.) \\ 2 Department of Ecology and Ecosystem Management, Technical University of Munich, \\ Hans-Carl-von-Carlowitz-Platz 2, 85354 Freising, Germany \\ * Correspondence: eric.labelle@tum.de; Tel.: +49-(0)816-171-4760
}

Received: 25 May 2018; Accepted: 21 June 2018; Published: 24 June 2018

\begin{abstract}
Ground-based skidding operations performed with heavy machinery have drastic effects on forest soils, which normally culminate in an increased soil bulk density and removal of the litter layer. We aimed to assess the efficacy of different tree species litter on the recovery of soil physical, chemical, and biological properties over a 5-year period in the Hyrcanian forests, northern Iran. Therefore, treatments included 45 combinations of five treatments (undisturbed area-UND, untreated trail or bare soil- $\mathrm{U}$, and three leaf litter types: pure beech-B, beech-hornbeam-B-H, and beech-hornbeam-maple-B-H-M) replicated in three plots in three transects. Results show that the highest litter thickness, and concentrations of $\mathrm{C}$ and $\mathrm{N}$ in the litter were observed in the UND treatment. The litter $\mathrm{C} / \mathrm{N}$ ratios were highest in the untreated trail $(\mathrm{U} ; 27.52)$ followed by $\mathrm{B}>\mathrm{B}-\mathrm{H} \approx$ B-H-M > UND treatments. The highest recovery of soil bulk density, total porosity, macroporosity, soil penetration resistance, and aggregate stability was observed on the $\mathrm{B}-\mathrm{H}-\mathrm{M}$ and $\mathrm{B}-\mathrm{H}$ treatment followed by the $B$ treatment. The highest recovery values of $\mathrm{pH}, \mathrm{C}, \mathrm{N}, \mathrm{C} / \mathrm{N}$ ratio, $\mathrm{C}$ and $\mathrm{N}$ sequestration recovery rates were observed on the B-H-M treatment, followed by the B-H treatment. Significantly higher values of available nutrients $(\mathrm{P}, \mathrm{K}, \mathrm{Ca}$, and $\mathrm{Mg})$, earthworm density, and biomass were found in the UND treatment followed by $\mathrm{B}-\mathrm{H}-\mathrm{M} \approx \mathrm{B}-\mathrm{H}>\mathrm{B}$ treatment, while the lowest amounts of available $\mathrm{P}$, $\mathrm{K}, \mathrm{Ca}$, and $\mathrm{Mg}$ were detected for the $\mathrm{U}$ trail. The high-quality litter species (hornbeam and maple) allowed for better recovery of the soil organic matter and increased nutrient availability compared to the lower quality litter (beech). We can conclude that by applying the different litters on compacted soil, the measured soil properties were significantly improved at the $\mathrm{B}, \mathrm{B}-\mathrm{H}$, and B-H-M treatments. Nevertheless, the soil properties following the B, B-H, and B-H-M treatments still demonstrated significant differences with the UND treatment, even over a 5-year period.
\end{abstract}

Keywords: leave litter; beech; hornbeam; maple; forest soils; soil properties; recovery

\section{Introduction}

Ground-based skidding operations are done with heavy machinery and normally entail machine traffic and load movement performed directly on forest soils. These mechanized activities can have severe effects on the quality of the forest soil [1-3], decrease total porosity [4,5], increase penetration resistance [6], decrease gas exchange [7], reduce water infiltration rate [8,9], and remove litter layer [10]. As a consequence, the bare mineral soil is exposed to the raindrops and throughfall impacts [11,12], which in turn increases the frequency of detached soil particles $[13,14]$, increases overland flow [9], develops rill and interrill $[15,16]$, transports the detached soil particles $[17,18]$, and increases sediments to downstream networks [14]. In addition, soil disturbances and litter layer 
removal due to ground-based skidding operations lessen forest soil not only by creating shortcomings to the nutrient cycling, but also by altering the mineralization processes of organic matter content, soil structures, and stability $[5,19]$.

At the end of each foliage period, the falling leaves contribute to the litter layer, which in turn absorbs raindrops and throughfall impacts, prevents soil particle detachment, increases infiltration rate, deceases evaporation from surface soil, regulates the temperature fluctuation between atmosphere and soil surface, and intercepts throughfall and solar radiations [20-23]. Consequently, the litter layer abates overland flow and subsequent soil loss [19].

The litter has two important roles in the forest stands: Firstly, as it covers the soil surface, it acts as a protective layer that can absorb raindrops, thereby mitigating runoff, soil particle detachment, and sediment transport [19]. However, based on previous studies, this first role of litter is more important than the cover canopy role $[21,23,24]$. Secondly, litter is an input and supply of nutrients flow and carbon cycling [19].

Mulch is organic or inorganic material (e.g., litter, leaves, agricultural straw, wood strands, wood fiber, hydromulch, etc.) that is scattered over a bare soil surface to provide protective cover and decrease raindrop energy and splash [18,25-27]. The application of biomaterial such as mulch on the bare soil surface not only mitigates runoff and soil loss $[18,25,28]$, but also assists in rehabilitating soil characteristics to pre-impact condition especially in the upper soil layer [29-34]. In this research, soil disturbance is defined in terms of mixing and/or removal of litter and soil, which may change the physical, chemical or biological properties of a soil [4]. Depending on the equipment used the surface soils are variously mixed, buried or inverted [3].

Previous studies have proven that machine-induced soil compaction is a long-lasting process [5,35-39], and its natural recovery occurs under natural processes such as root-soil interactions, expansion-retraction of clay particles, freezing-thawing of soil water, and biological activity of soil organisms $[37,40]$. Ezzati et al. [41] reported that soil bulk density and total porosity did not naturally recover over a 20-year period following skidding operations in the Hyrcanian forest. One of the foremost solutions to accelerate the recovery process of physical properties on the compacted soils is the application of biological measures involving the use of mulches, earthworms, etc., which results in a stimulation of the biological activities [40].

Previous studies also reported that different leaf litterfall regulates the physical, chemical, and biological properties of the forest floor as well as soil and nutrients cycling [42-45]. However, factors such as bedrock, climate, tree and shrub species can also influence soil fertility [42].

High-quality litter, such as maple, hornbeam and alder, have high nutrition and N, low carbon and lignin, faster decomposition rate, high $\mathrm{C} / \mathrm{N}$ ratio, and lower acidity, which leads to increased biological activity of macro- and micro-organisms and soil fauna such as earthworms $[19,40,43]$. By improving the soil $\mathrm{pH}$, both anecic and endogeic earthworms start to burrow the soil horizontally, thus leading to increased soil aeration, increased stability of aggregates, increased macroporosity, and decreased soil bulk density [40,46-48]. Ampoorter et al. [40] concluded that the high decay rate of Populus $x$ canadensis could be achieved due to high available nutrients and $\mathrm{C} / \mathrm{N}$ ratio by altering the composition of the litter layer. In the European forest, $\mathrm{C} / \mathrm{N}$ ratio in forest floor and mineral soil was highly dependent on tree species $[47,48]$.

In the arable lands, Mulumba and Lal [30] (2008) reported that total porosity increased following mulch application compared to an untreated area. Jordán et al. [32] (2010) stated that certain soil properties such as the organic matter content, bulk density, total porosity, and aggregate stability were improved by mulch application. Lombao et al. [33] (2015) found that mulch application post-fire had little effect on soil properties such as $\mathrm{pH}$, total $\mathrm{C}$, moisture and water retention.

So far, several studies have been conducted on the hydrological functions of litters in controlled laboratory conditions using rainfall simulators [20,23,49-51]. Furthermore, different litter rates or masses, species types, and rainfall intensities have been investigated in these studies. However, no study has been performed on the effects of tree species litter as mulch on compacted soil restoration in the skid trails under natural growing conditions. In the current study, we aimed to: (1) assess the 
efficacy of different tree species litter on the recovery of soil physical, chemical, and biological properties, compared to untreated skid trail (U), and undisturbed (UND) over a 5-year period; (2) test the tree litter mulches as ecological restoration options on the surface soil in the skid trail under natural conditions.

\section{Materials and Methods}

\subsection{Site Description}

Compartment no. 319 of the Gorazbon district in the Kheyrud Educational and Research forest of the University of Tehran was selected for this study $\left(36^{\circ} 33^{\prime} \mathrm{N}, 50^{\circ} 33^{\prime} \mathrm{E}\right.$; Figure 1a). The study area was located at an altitude of 1190-1270 m above sea level and lies on a southern aspect. Average annual precipitation is $1260 \mathrm{~mm}_{\text {year }}^{-1}$ with most of this falling in summer and autumn. More specifically, the average rainfalls in the study area for the years 2012 to 2017 were 1628.1, 1558, 1118.9, 1408.4 and $1612 \mathrm{~mm}$, respectively. Monthly rainfall varied from $5.8 \mathrm{~mm}$ in April 2012 to $356.1 \mathrm{~mm}$ in November 2012. The annual average temperature is about $24.6^{\circ} \mathrm{C}$ during the hottest month and $0{ }^{\circ} \mathrm{C}$ during coldest months (December to February). Soils are predominantly deep brown, with well-drained loam texture derived from limestone and dolomite limestone, which belong to the upper Jurassic and lower Cretaceous periods. The soil of study site is classified as a brown forest soil (Alfisols). The study area is dominated by natural forests with native mixed deciduous tree species, including beech (Fagus orientalis Lipsky), hornbeam (Carpinus betulus L.), oak (Quercus castaneifolia C.A.M.), alder (Alnus subcordata C.A.M.), and velvet maple (Acer velutinum Boiss.) according to aspect, soil moisture, and altitude. The dominant silvicultural treatment is a combination of group selection and single tree selection. The average growing stock in our compartment was $554 \mathrm{~m}^{3} \mathrm{ha}^{-1}$. Tree felling and delimbing was performed motor-manually with chain-saws. The prepared logs with a length of $5-15 \mathrm{~m}$ were extracted by a Timberjack $450 \mathrm{C}$ wheeled cable skidder to the roadside landings. The skidder was fitted with size 24.5-32 tires inflated to $220 \mathrm{kPa}$ on both front and rear axles, and it had a ground clearance of approximately $0.6 \mathrm{~m}$ with an overall width of $3.1 \mathrm{~m}$. The skidding operation occurred in July 2012. Within our study areas, the average skidding load was $3.8 \mathrm{~m}^{3}$ per pass and the skid trail longitudinal gradient ranged from 4 to $21 \%$.

\subsection{Experimental Design}

In order to assess the efficacy of leaf litter mulching on ecological restoration of compacted soil, four skid trails with downhill skidding direction were selected, and sampling plots were established in different skid trail segments on trail gradients of $15-20 \%$ exposed to high levels of machine traffic (high; >15 machine cycles). One empty and one loaded pass on the skid trail was considered as a machine cycle [9]. Five sample plots measuring $20 \mathrm{~m}$ in length and $4 \mathrm{~m}$ in width were selected. From these, three plots were then randomly established for leaf litter study. In each selected sample plot, five transects were established perpendicular to the longitudinal axis of the skid trail at $4 \mathrm{~m}$ interval and three of those transects were randomly selected for study. Alongside each sample plot, a control area was established under canopy cover of mixed beech-hornbeam-maple stands in the untrafficked area at a $20 \mathrm{~m}$ distance from skid trails to compare with the samples in each plot (compacted) and assess the recovery process. The plot establishment was carried out in July 2012. At the time of skidding, weather conditions had been very dry and warm, and these conditions remained constant throughout the wood extraction operation. Immediately after the skidding operation, $2 \mathrm{~m}^{2}$ micro-plots $(2 \mathrm{~m}$ long $\times 1 \mathrm{~m}$ width) were established for each treatment on the skid trail (Figure 1b). Each micro-plot was bordered by wooden pieces placed to a depth of $20 \mathrm{~cm}$ inside the soil and protruded about $15 \mathrm{~cm}$ above the soil surface to prevent input from the adjacent area [18]. Therefore, treatments included 45 combinations of five treatments (undisturbed area-UND, untreated trail or bare soil- $\mathrm{U}$, and three leaf litter types: pure beech-B, beech-hornbeam-B-H, and beech-hornbeam-maple-B-H-M) replicated in three plots in three transects (Figure 1c,d).

Accordingly, leaf litter of beech (Fagus orientalis Lipsky), hornbeam (Carpinus betulus L.), and velvet maple (Acer velutinum Boiss.) were collected and applied in this study. To provide a combination 
1:1 litter weight of beech, hornbeam, and maple, three pure stands of these species, each with an area of one hectare were selected and each area was divided in 16 micro-plots, of which 10 micro-plots were randomly selected. In each selected micro-plots, three samples of fallen leaves in a $5 \mathrm{~m}^{2}$ area were collected. Since the biological activity and litter decomposition processes are also ongoing in the microplate substrate, the undecomposed litters were collected as mulch application, so that type of species could easily be identified from the litters [20,51]. These leaf litters were collected manually, placed in plastic bags, transported to the laboratory, and air-dried. In the laboratory, the twigs and decomposed litters were excluded from the undecomposed litters and weighed. To ensure that the litters used in runoff plots were similar to the natural conditions of forest stands in the study area, leaf litters were combined as a weight ratio of 1:1 beech, hornbeam, and maple according to weight ratio. A litter rate of $1.8 \mathrm{~kg} \mathrm{~m}^{-2}$ was applied directly in the forest test areas as mulch over the skid trail surface to test the soil and litter physical, chemical, and biological properties over a five-year period. Immediately after skidding operations, plots were installed and the weighed and labeled litters were transported to the study area in plastic bags, and were carefully distributed by hand on plot surfaces with rates of $1.8 \mathrm{~kg} \mathrm{~m}^{-2}\left(\mathrm{~B}=1.8 \mathrm{~kg} \mathrm{~m}^{-2} \mathrm{~B}, \mathrm{~B}-\mathrm{H}=0.9 \mathrm{~kg} \mathrm{~m}^{-2} \mathrm{~B}+0.9 \mathrm{~kg} \mathrm{~m}^{-2} \mathrm{H}, \mathrm{B}-\mathrm{H}-\mathrm{M}=0.6 \mathrm{~kg} \mathrm{~m}^{-2}\right.$ $\left.\mathrm{B}+0.6 \mathrm{~kg} \mathrm{~m}^{-2} \mathrm{H}+0.6 \mathrm{~kg} \mathrm{~m}^{-2} \mathrm{M}\right)$. Plot surfaces were then covered with a wire mesh to prevent the entry of falling leaves and twigs from the canopy.

In each treatment, nine sample plots were measured, thus providing 27 soil samples. In total, 135 (i.e., 3 plots at each trail $\times 3$ transects at each plot $\times 3$ samples in each transect $\times 5$ treatments) soil samples were collected and analyzed in July 2017. Because certain soil property measurements are highly affected by soil moisture, a dry day was chosen to ensure soils were at dry and rather uniform condition and all measurements were performed on that same day. Meanwhile, three soil samples were collected in each plot in three sample points.

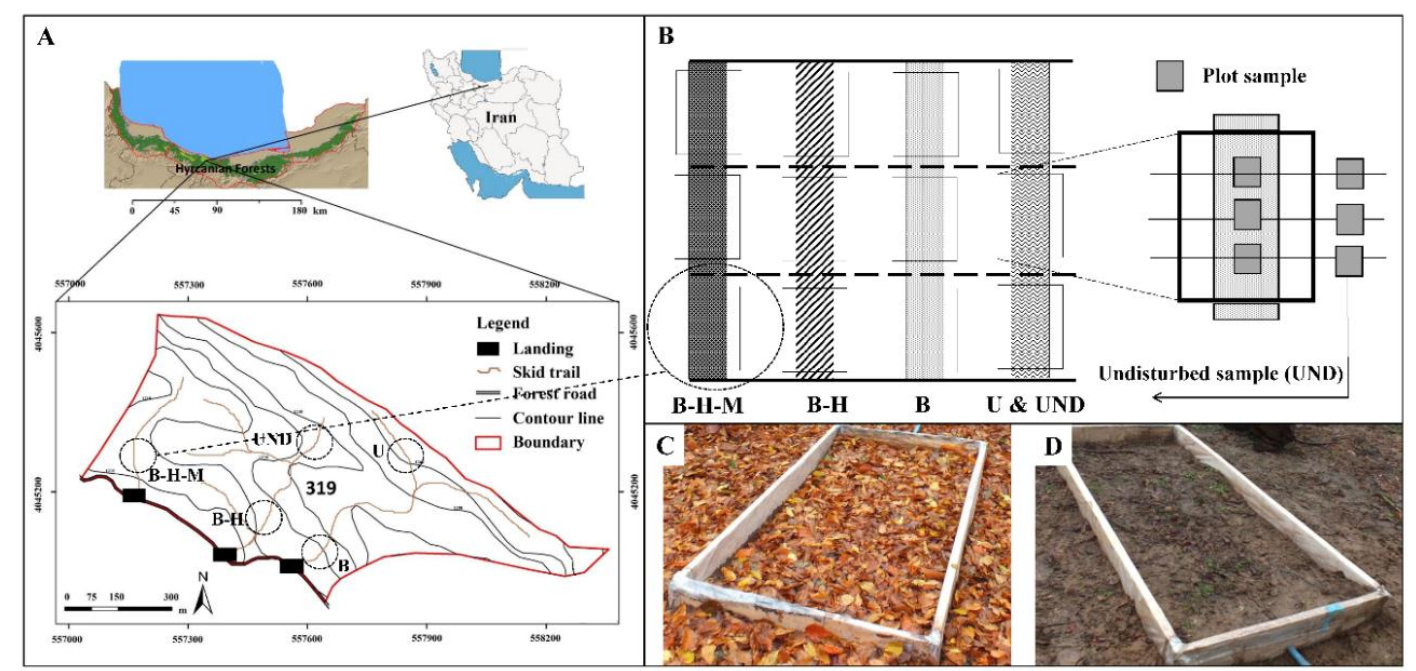

Figure 1. Layout of the study area in the Gorazbon District in the Hyrcanian forests (A), schematic of the experimental design on the skid trail; different treatments are included: Untreated trail (U), Undisturbed area (UND), Pure Beech litter (B), litter of Beech-Hornbeam (B-H), mixed litter of Beech-Hornbeam-Maple (B-H-M) (B), litter of pure beech (C), untreated trail (D).

\subsection{Data Collection and Laboratory Analysis}

After a 5-year period, litter depth or thickness was determined using a tape measure. Litter samples were labeled and immediately transported to the laboratory, and then cleaned and oven-dried at $65^{\circ} \mathrm{C}$ for $48 \mathrm{~h}$. The $\mathrm{C}$ and $\mathrm{N}$ concentrations of litter samples were measured using a $\mathrm{CN}$ elemental analyzer (Flash EA1112 Series; Thermo Finnigan, Milan, Italy; [52]). Soil sample cores were taken from the top mineral soil (from soil surface down to a depth of $10 \mathrm{~cm}$ ) using a thin walled steel cylinder, $100 \mathrm{~mm}$ long and $56 \mathrm{~mm}$ in diameter, driven horizontally into the soil by a hammer-driven device. 
After extracting the steel cylinder, soil cores were trimmed flush with the cylinder ends and extruded into a plastic bag for transport to the laboratory. Samples were weighed on the day they were collected and again after oven drying at $105^{\circ} \mathrm{C}$ until constant mass was reached to determine water content and bulk density. Soil particle size distribution for particles smaller than $0.075 \mathrm{~mm}$ was determined using the hydrometer method [53] and larger particles were sieved through a series of sieves of varying apertures. Macroporosity was determined using the water desorption method [54]. Soil penetration resistance (PR) was measured using an analog hand-held soil penetrometer that was inserted vertically into the soil. Each sample point contained one PR measurement. Because PR measurements are highly influenced by soil moisture, a dry day was chosen to ensure soils were at dry conditions, and all measurements were performed on the same day to ensure that soil moisture conditions were relatively uniform within all sites. The aggregate stability was determined by a wet sieving procedure [55]. To calculate total porosity, first soil particle density was determined according to the ASTM D854-00 2000 standard and then Equation (1) was used as follows:

$$
\mathrm{TP}=\frac{1-\frac{\mathrm{BD}}{2.65}}{\mathrm{VC}}
$$

where TP is the apparent total porosity (\%), BD is the bulk density $\left(\mathrm{g} \mathrm{cm}^{-3}\right), 2.65\left(\mathrm{~g} \mathrm{~cm}^{-3}\right)$ is the particle density, and VC is the volume of the intact soil cores $\left(246.30 \mathrm{~cm}^{3}\right)$.

Organic horizons were removed from the soil surface prior to collecting soil samples, to ensure measurements were referenced to the mineral soil surface. Samples were sealed in plastic bags, labeled, and transported to the laboratory. Soil samples were air-dried at room temperature and then sieved through a 2-mm sieve. After sieving, the following soil chemical properties were determined: The $\mathrm{pH}$ was determined by an Orion Ionalyzer (Model 901) $\mathrm{pH}$ meter in a soil:water ratio of 1:2.5 and EC was determined using an Orion Ionalyzer EC meter in a 1:2.5 soil:water solution. Soil organic $C$ was determined using the Walkley-Black technique [56] and total $\mathrm{N}$ was measured using the Kjeldahl method [57]. Soil $\mathrm{C}$ and $\mathrm{N}$ sequestration at depth of $0-10 \mathrm{~cm}$ was calculated as Equation (2):

$$
\mathrm{SO}(\mathrm{C} \text { or } \mathrm{N}) \mathrm{s}=\mathrm{C} \text { or } \mathrm{N} \times \mathrm{BD} \times \mathrm{e} \times 0.1 \mathrm{SO}(\mathrm{C} \text { or } \mathrm{N}) \mathrm{s}=\mathrm{C} \text { or } \mathrm{N} \times \mathrm{BD} \times \mathrm{e} \times 0.1
$$

where the $\mathrm{SO}(\mathrm{C}$ or $\mathrm{N}) \mathrm{s}$ indicates the organic $\mathrm{C}$ or $\mathrm{N}$ sequestration at soil $\left(\mathrm{Mg} \mathrm{ha}^{-1}\right) ; \mathrm{C}$ or $\mathrm{N}$ is the organic $\mathrm{C}$ or $\mathrm{N}$ content $\left(\mathrm{g} \mathrm{kg}^{-1}\right)$; $\mathrm{BD}$ is the bulk density $\left(\mathrm{g} \mathrm{cm}^{-3}\right)$; e is the thickness of the layers $(\mathrm{cm})$, and 0.1 is a conversion factor.

Available P was determined with a spectrophotometer using the Olsen method, and available K, $\mathrm{Ca}$, and $\mathrm{Mg}$ (by ammonium acetate extraction at $\mathrm{pH} 9$ ) were determined with an atomic absorption spectrophotometer [58]. Sampling was done manually at the surface soil with $25 \times 25 \mathrm{~cm}$ and $0-10 \mathrm{~cm}$ depths to count the number and density of earthworms. Earthworms were oven dried at $60^{\circ} \mathrm{C}$ for $24 \mathrm{~h}$ to determine the earthworm biomass.

\subsection{Statistical Analyses}

The experimental design was completely randomized, whereby plots were randomly assigned to the treatments. Generalized linear modeling (GLM, one-way analysis of variance) was applied to relate soil property responses with treatment. Since no departure of the data from a normal distribution was determined by the Kolmogorov-Smirnov test $(\alpha=0.05)$, standard parametric analyses were carried out. Homogeneity of variance among treatments was verified by Levene's test $(\alpha=0.01)$. Post hoc comparisons of the treatment group means were performed using Tukey test with a 95\% confidence level. Treatment effects were considered statistically significant when $p \leq 0.05$. SPSS (release 17.0; SPSS, Chicago, IL, USA) statistical package was used for analyses. Principal component analysis (PCA) is a multivariate analysis method that investigates complex relationships among variables. Multivariate correlations were used to determine significant relationships among variables and principal components using the XLSTAT 2016 software. 


\section{Results}

\subsection{Litter Properties}

Results show that the highest litter thickness, $\mathrm{C}$, and $\mathrm{N}$ of litter were observed in the UND treatment, and significantly differed from the other treatments (Table 1), while the lowest values of litter thickness, $C$, and $N$ were measured on the $U$ trail. The litter $C / N$ ratio were highest in the untreated trail (U; 27.52) followed by B > B-H $\approx$ B-H-M > UND treatments (Table 1).

Table 1. Means ( \pm std) of litter properties in the five treatments. UND = Undisturbed area; Beech (Fagus orientalis) + hornbeam (Carpinus betulus) + velvet maple (Acer velutinum), B-H-M = Mixed beech = Beech + hornbeam + velvet maple, $\mathrm{B}-\mathrm{H}=$ Beech-hornbeam, $\mathrm{B}=$ Pure beech, $\mathrm{U}=$ Untreated trail.

\begin{tabular}{|c|c|c|c|c|c|c|c|}
\hline Variable & $\begin{array}{l}\text { Undisturbed } \\
\text { Area (UND) }\end{array}$ & Mixed Beech & Beech-Hornbeam & Pure Beech & $\begin{array}{c}\text { Untreated Trail } \\
\text { (U) }\end{array}$ & $F$ Test & $\begin{array}{c}p \\
\text { Value }\end{array}$ \\
\hline Thickness (cm) & $10.2 \pm 1.41 \mathrm{a}$ & $4.8 \pm 0.94 c$ & $4.7 \pm 0.89 c$ & $6.2 \pm 1.17 \mathrm{~b}$ & $2.6 \pm 0.97 d$ & 180.62 & 0.000 \\
\hline $\mathrm{C}(\%)$ & $19.62 \pm 2.09 a$ & $11.46 \pm 2.11 c$ & $9.34 \pm 2.49 \mathrm{~d}$ & $14.12 \pm 1.68 \mathrm{~b}$ & $5.32 \pm 1.0 \mathrm{e}$ & 205.02 & 0.000 \\
\hline $\mathrm{N}(\%)$ & $2.24 \pm 0.16 a$ & $1.23 \pm 0.15 b$ & $1.15 \pm 0.13 b$ & $0.64 \pm 0.12 c$ & $0.23 \pm 0.1 \mathrm{~d}$ & 861.26 & 0.000 \\
\hline $\mathrm{C} / \mathrm{N}$ ratio & $8.85 \pm 1.49 c$ & $9.43 \pm 2.01 c$ & $7.99 \pm 1.3 c$ & $22.39 \pm 2.27 b$ & $27.52 \pm 11.2 \mathrm{a}$ & 80.30 & 0.000 \\
\hline
\end{tabular}

Note: Results of the ANOVAs ( $F$ test and $p$ value) are given. Different letters after means within each treatment indicate significant differences by Tukey test $(p<0.05)$.

\subsection{Soil Physical Properties}

The highest soil bulk density values were found on the U treatment (1.36) followed by B > B-H > B-H-M treatment (Table 2).

The highest total porosity and macroporosity of 57.5 and $54.2 \%$ were measured in the UND treatment, and total porosity and macroporosity significantly differed among the different litter treatments.

Soil penetration resistance, soil moisture, and sand content were higher in the $U$ trail than in litters treatment plots and UND treatment (Table 2). Soil aggregate stability and clay content were significantly higher in the UND treatment than in litter treatment plots and $U$ treatment (Table 2). The silt content was significantly higher for the B-H and B-H-M treatments than under B $>$ UND > U (Table 2).

\subsection{Soil Chemical Properties}

Treatments had a significant effect on $\mathrm{pH}, \mathrm{EC}, \mathrm{C}, \mathrm{N}$, and soil $\mathrm{C} / \mathrm{N}$ ratio available, $\mathrm{C}$ sequestration, $\mathrm{N}$ sequestration, and available nutrients ( $\mathrm{P}, \mathrm{K}, \mathrm{Ca}$, and $\mathrm{Mg}$ ) (Table 3). The highest soil $\mathrm{pH}$ and EC values were measured at the UND treatment (6.78 and 0.34) followed by B-H-M and B-H treatments, whereas the lowest $\mathrm{pH}$ and $\mathrm{EC}$ values were detected on the $\mathrm{B}$ and $\mathrm{U}$ treatments (Table 3 ). The soil organic $\mathrm{C}$ values were highest in the UND (2.68\%) followed by B-H-M $\approx \mathrm{B}-\mathrm{H}>\mathrm{B}>\mathrm{U}$ treatment.

The highest total $\mathrm{N}$ was observed in the UND treatment $(0.49 \%)$ followed by B-H-M $\approx \mathrm{B}-\mathrm{H}>\mathrm{B}>$ $\mathrm{U}$ treatment. The $\mathrm{C} / \mathrm{N}$ ratio was significantly higher on the $\mathrm{U}$ trail, $14.2 \%$ than under $\mathrm{B}>\mathrm{B}-\mathrm{H}-\mathrm{M} \approx$ $\mathrm{B}-\mathrm{H}>\mathrm{UND}$ treatments. Significantly higher values of $\mathrm{C}$ and $\mathrm{N}$ sequestration were found in the UND followed by B-H-M $\approx \mathrm{B}-\mathrm{H}>\mathrm{B}>\mathrm{U}$ treatment. Significantly higher values of available nutrients $(\mathrm{P}, \mathrm{K}$, $\mathrm{Ca}$, and $\mathrm{Mg}$ ) were found in the UND treatment followed by $\mathrm{B}-\mathrm{H}-\mathrm{M} \approx \mathrm{B}-\mathrm{H}>\mathrm{B}$ treatment, while the lowest amounts of available $\mathrm{P}, \mathrm{K}, \mathrm{Ca}$, and $\mathrm{Mg}$ were detected at $\mathrm{U}$ treatment.

\subsection{Soil Biological Properties}

The earthworm density $\left(1.86\right.$ number $\left.\mathrm{m}^{-2}\right)$ and biomass $\left(25.81 \mathrm{mg} \mathrm{m}^{-2}\right)$ were significantly higher on the $\mathrm{U}$ treatment than under $\mathrm{B}-\mathrm{H}-\mathrm{M} \approx \mathrm{B}-\mathrm{H}>\mathrm{B}$ treatments, while the lowest values of earthworm density and biomass by $0.32 \mathrm{n} \mathrm{m}^{-2}$ and $4.17 \mathrm{mg} \mathrm{m}^{-2}$ were observed on the $\mathrm{U}$ treatment (Table 4). 
Table 2. Means $( \pm \mathrm{std})$ of soil physical properties in the five treatments. UND $=$ Undisturbed area; Beech (Fagus orientalis $)+$ hornbeam $($ Carpinus betulus $)+$ velvet maple (Acer velutinum), B-H-M = Mixed beech = Beech + hornbeam + velvet maple, $\mathrm{B}-\mathrm{H}=$ Beech-hornbeam, $\mathrm{B}=\mathrm{Pure}$ beech, $\mathrm{U}=\mathrm{Untreated}$ trail.

\begin{tabular}{|c|c|c|c|c|c|c|c|}
\hline Variable & Undisturbed Area (UND) & Mixed Beech & Beech-Hornbeam & Pure Beech & Untreated Trail (U) & $F$ Test & $p$ Value \\
\hline Bulk density $\left(\mathrm{g} \mathrm{cm}^{-3}\right)$ & $1.08 \pm 0.06 \mathrm{~d}$ & $1.18 \pm 0.07 \mathrm{c}$ & $1.21 \pm 0.07 \mathrm{c}$ & $1.28 \pm 0.07 \mathrm{~b}$ & $1.36 \pm 0.1 \mathrm{a}$ & 53.32 & 0.000 \\
\hline Total porosity $(\%)$ & $57.48 \pm 2.34 a$ & $52.99 \pm 2.88 \mathrm{~b}$ & $51.98 \pm 2.86 \mathrm{~b}$ & $49.61 \pm 2.58 c$ & $46.88 \pm 3.9 \mathrm{~d}$ & 48.47 & 0.000 \\
\hline Macroporosity (\%) & $54.21 \pm 1.28 \mathrm{a}$ & $42.36 \pm 0.82 \mathrm{~b}$ & $38.47 \pm 0.87 \mathrm{c}$ & $39.61 \pm 1.36 \mathrm{c}$ & $36.11 \pm 0.97 \mathrm{~d}$ & 1164.44 & 0.000 \\
\hline Penetration resistance (MPa) & $1.12 \pm 0.14 \mathrm{~d}$ & $1.58 \pm 0.11 \mathrm{c}$ & $1.62 \pm 0.11 \mathrm{c}$ & $2.11 \pm 0.11 \mathrm{~b}$ & $2.47 \pm 0.08 \mathrm{a}$ & 581.18 & 0.000 \\
\hline Soil moisture (\%) & $19.52 \pm 1.58 c$ & $20.41 \pm 2.77 \mathrm{bc}$ & $18.23 \pm 1.56 \mathrm{~d}$ & $21.17 \pm 1.41 \mathrm{~b}$ & $26.72 \pm 1.36 \mathrm{a}$ & 137.54 & 0.000 \\
\hline Aggregate stability (\%) & $68.34 \pm 3.56 a$ & $49.19 \pm 2.77 \mathrm{~b}$ & $48.61 \pm 1.52 b$ & $29.28 \pm 1.42 c$ & $23.47 \pm 1.39 \mathrm{~d}$ & 1622.37 & 0.000 \\
\hline Sand $(\%)$ & $21.75 \pm 1.33 \mathrm{~d}$ & $23.84 \pm 1.44 \mathrm{c}$ & $24.64 \pm 1.4 \mathrm{c}$ & $31.43 \pm 1.72 \mathrm{~b}$ & $37.26 \pm 1.77 \mathrm{a}$ & 466.75 & 0.000 \\
\hline Silt (\%) & $42.98 \pm 1.62 \mathrm{c}$ & $46.3 \pm 1.46 a$ & $47.01 \pm 0.92 \mathrm{a}$ & $44.43 \pm 2.25 b$ & $41.61 \pm 1.42 \mathrm{~d}$ & 53.99 & 0.000 \\
\hline Clay (\%) & $35.27 \pm 1.86 a$ & $29.86 \pm 1.93 \mathrm{~b}$ & $28.86 \pm 1.91 \mathrm{~b}$ & $24.14 \pm 2 c$ & $21.13 \pm 2.13 \mathrm{~d}$ & 207.60 & 0.000 \\
\hline
\end{tabular}

Note: Results of the ANOVAs ( $F$ test and $p$ value) are given. Different letters after means within each treatment indicate significant differences by Tukey test $(p<0.05)$.

Table 3. Means $( \pm$ std) of soil chemical properties in the five treatments. UND $=$ Undisturbed area; Beech (Fagus orientalis) + hornbeam (Carpinus betulus) + velvet maple $($ Acer velutinum), B-H-M = Mixed beech = Beech + hornbeam + velvet maple, $\mathrm{B}-\mathrm{H}=$ Beech-hornbeam, $\mathrm{B}=\mathrm{Pure}$ beech, $\mathrm{U}=\mathrm{Untreated}$ trail.

\begin{tabular}{|c|c|c|c|c|c|c|c|}
\hline Variable & Undisturbed Area (UND) & Mixed Beech & Beech-Hornbeam & Pure Beech & Untreated Trail (U) & $F$ Test & $p$ Value \\
\hline $\mathrm{pH}\left(1: 2.5 \mathrm{H}_{2} \mathrm{O}\right)$ & $6.78 \pm 0.15 a$ & $6.12 \pm 0.15 b$ & $6.07 \pm 0.14 \mathrm{~b}$ & $5.62 \pm 0.15 c$ & $5.37 \pm 0.14 \mathrm{~d}$ & 382.73 & 0.000 \\
\hline $\mathrm{Ec}(\mathrm{ds} / \mathrm{m})$ & $0.34 \pm 0.01 \mathrm{a}$ & $0.27 \pm 0.01 \mathrm{~b}$ & $0.26 \pm 0.01 b$ & $0.22 \pm 0.01 c$ & $0.19 \pm 0.02 \mathrm{~d}$ & 464.64 & 0.000 \\
\hline C (\%) & $2.68 \pm 0.04 a$ & $2.12 \pm 0.08 \mathrm{~b}$ & $2.09 \pm 0.05 b$ & $1.68 \pm 0.06 c$ & $1.25 \pm 0.04 \mathrm{~d}$ & 2285.34 & 0.000 \\
\hline $\mathrm{N}(\%)$ & $0.49 \pm 0.03 a$ & $0.28 \pm 0.01 b$ & $0.27 \pm 0.01 \mathrm{~b}$ & $0.16 \pm 0.02 c$ & $0.09 \pm 0.01 \mathrm{~d}$ & 2300.45 & 0.000 \\
\hline $\mathrm{C} / \mathrm{N}$ ratio & $5.48 \pm 0.22 \mathrm{~d}$ & $7.58 \pm 0.15 c$ & $7.75 \pm 0.19 c$ & $10.56 \pm 0.67 \mathrm{~b}$ & $14.17 \pm 2.28 \mathrm{a}$ & 263.55 & 0.000 \\
\hline $\mathrm{C}$ sequestration $\left(\mathrm{Mg} \mathrm{ha}^{-1}\right)$ & $28.92 \pm 1.2 \mathrm{a}$ & $24.97 \pm 0.82 b$ & $25.26 \pm 0.98 \mathrm{~b}$ & $21.47 \pm 0.41 \mathrm{c}$ & $17.03 \pm 1.77 \mathrm{~d}$ & 425.80 & 0.000 \\
\hline $\mathrm{N}$ sequestration $\left(\mathrm{Mg} \mathrm{ha}^{-1}\right)$ & $5.28 \pm 0.17 \mathrm{a}$ & $3.3 \pm 0.08 \mathrm{~b}$ & $3.26 \pm 0.09 b$ & $2.04 \pm 0.11 c$ & $1.22 \pm 0.11 \mathrm{~d}$ & 4731.14 & 0.000 \\
\hline Available $\mathrm{P}\left(\mathrm{mg} \mathrm{kg}^{-1}\right)$ & $28.36 \pm 3.06 a$ & $19.85 \pm 1.25 b$ & $19.31 \pm 1.14 \mathrm{~b}$ & $11.27 \pm 2.1 \mathrm{c}$ & $8.47 \pm 2.01 \mathrm{~d}$ & 403.97 & 0.000 \\
\hline Available $\mathrm{K}\left(\mathrm{mg} \mathrm{kg}^{-1}\right)$ & $263.48 \pm 13.03 a$ & $184.33 \pm 11.72 b$ & $178.62 \pm 12.9 b$ & $127.57 \pm 11.4 \mathrm{c}$ & $92.75 \pm 12.37 \mathrm{~d}$ & 748.88 & 0.000 \\
\hline Available $\mathrm{Ca}\left(\mathrm{mg} \mathrm{kg}^{-1}\right)$ & $237.53 \pm 17.34 a$ & $142.81 \pm 15.99 \mathrm{~b}$ & $137.44 \pm 12.3 \mathrm{~b}$ & $96.71 \pm 13.4 \mathrm{c}$ & $79.67 \pm 13.35 \mathrm{~d}$ & 476.11 & 0.000 \\
\hline Available $\mathrm{Mg}\left(\mathrm{mg} \mathrm{kg}^{-1}\right)$ & $54.76 \pm 6.58 \mathrm{a}$ & $42.37 \pm 4.08 \mathrm{~b}$ & $39.65 \pm 3.2 b$ & $27.43 \pm 4.15 c$ & $20.68 \pm 3.44 \mathrm{~d}$ & 241.33 & 0.000 \\
\hline
\end{tabular}

Note: Results of the ANOVAs ( $F$ test and $p$ value) are given. Different letters after means within each treatment indicate significant differences by Tukey test $(p<0.05)$.

Table 4. Means ( \pm std) of soil biological properties in the five treatments. UND = Undisturbed area; Beech (Fagus orientalis) + hornbeam (Carpinus betulus) + velvet maple (Acer velutinum), B-H-M = Mixed beech = Beech + hornbeam + velvet maple, $\mathrm{B}-\mathrm{H}=$ Beech-hornbeam, $\mathrm{B}=\mathrm{Pure}$ beech, $\mathrm{U}=\mathrm{Untreated}$ trail.

\begin{tabular}{cccccccc}
\hline Variable & Undisturbed Area (UND) & Mixed Beech & Beech-Hornbeam & Pure Beech & Untreated Trail (U) & $\boldsymbol{F}$ Test & $\boldsymbol{P}$ Value \\
\hline Earthworm density $\left(\mathrm{n} \mathrm{m}^{-2}\right)$ & $1.86 \pm 0.15 \mathrm{a}$ & $1.02 \pm 0.14 \mathrm{~b}$ & $0.96 \pm 0.13 \mathrm{~b}$ & $0.54 \pm 0.07 \mathrm{c}$ & $0.32 \pm 0.07 \mathrm{~d}$ & 718.20 & 0.000 \\
Earthworm biomass $\left(\mathrm{mg} \mathrm{m}^{-2}\right)$ & $25.81 \pm 2.35 \mathrm{a}$ & $13.26 \pm 2.01 \mathrm{~b}$ & $12.47 \pm 2.02 \mathrm{~b}$ & $7.02 \pm 1.73 \mathrm{c}$ & $4.17 \pm 1.49 \mathrm{~d}$ & 495.79 & 0.000 \\
\hline
\end{tabular}

Note: Results of the ANOVAs ( $F$ test and $p$ value) are given. Different letters after means within each treatment indicate significant differences by Tukey test $(p<0.05)$ 


\subsection{The Recovery Rate of Soil Properties}

The percentages of recovery for the tested soil properties are presented in Table 5 . The highest litter $\mathrm{C} / \mathrm{N}$ ratio recovery rates of $71 \%$ and $66 \%$ were found in the $\mathrm{B}-\mathrm{H}$ and $\mathrm{B}-\mathrm{H}-\mathrm{M}$ treatments (Table 5 ). The highest recovery of soil bulk density was observed on the B-H-M $(91.5 \%) \approx \mathrm{B}-\mathrm{H}(89 \%)$ treatment followed by the $B$ treatment. After five years, the greatest recovery in total porosity was detected at the B-H-M and B-H treatments by $92.2 \%$ and $90.4 \%$, respectively. Over a 5-year period, the highest recovery values of soil penetration resistance were observed in the $\mathrm{B}-\mathrm{H}-\mathrm{M}, \mathrm{B}-\mathrm{H}$, and $\mathrm{B}$ treatment. The highest recovery rates of aggregate stability were observed on the B-H-M, B-H, and B treatments, compared to the UND treatment (Table 5). The highest recovery values of $\mathrm{pH}$ were observed on the $\mathrm{B}-\mathrm{H}-\mathrm{M}$ treatment, followed by the B-H treatment. The recovery of organic $\mathrm{C}$ at the B-H-M and B-H treatments was significantly higher than the values obtained under the $B$ and the UND treatments. The recovery values of total $\mathrm{N}$ were significantly higher at the B-H-M and B-H treatments than at the $\mathrm{B}$ treatment. The $\mathrm{C} / \mathrm{N}$ ratio recovery was higher on the $\mathrm{B}-\mathrm{H}-\mathrm{M}$ and $\mathrm{B}-\mathrm{H}$ treatments than in the $\mathrm{B}$ treatment. The highest $\mathrm{C}$ and $\mathrm{N}$ sequestration recovery rates were found in the B-H-M and $\mathrm{B}-\mathrm{H}$ treatments. The recovery values of available nutrients $(\mathrm{P}, \mathrm{K}, \mathrm{Ca}$, and $\mathrm{Mg}$ ) were higher on the $\mathrm{B}-\mathrm{H}-\mathrm{M}$ and $\mathrm{B}-\mathrm{H}$ than the $\mathrm{B}$ treatment. The highest earthworm density and biomass recoveries were observed in the B-H-M treatment followed by B-H > B treatments.

Table 5. Mean recovery rate of soil properties in the four treatments. B-H-M $=$ Mixed beech $=$ Beech + hornbeam + velvet maple, B-H = Beech-hornbeam, B = Pure beech, $\mathrm{U}=$ Untreated trail. Changes are relative to measurements from the same profile class in undisturbed area (UND). UND = Beech (Fagus orientalis) + hornbeam (Carpinus betulus) + velvet maple (Acer velutinum).

\begin{tabular}{|c|c|c|c|c|c|}
\hline \multirow{2}{*}{\multicolumn{2}{|c|}{ Variable }} & \multicolumn{4}{|c|}{ Recovery Rate (\%) } \\
\hline & & \multirow{2}{*}{$\begin{array}{c}\begin{array}{c}\text { Mixed } \\
\text { Beech }\end{array} \\
47.1\end{array}$} & \multirow{2}{*}{$\begin{array}{c}\begin{array}{c}\text { Beech- } \\
\text { Hornbeam }\end{array} \\
46.1\end{array}$} & \multirow{2}{*}{$\begin{array}{c}\begin{array}{c}\text { Pure } \\
\text { Beech }\end{array} \\
60.8\end{array}$} & \multirow{2}{*}{$\begin{array}{c}\begin{array}{c}\text { Untreated } \\
\text { Trail (U) }\end{array} \\
25.5\end{array}$} \\
\hline Litter properties & Thickness & & & & \\
\hline & C & 58.4 & 47.6 & 72 & 27.1 \\
\hline & $\mathrm{N}$ & 54.9 & 51.3 & 28.6 & 10.3 \\
\hline & $\mathrm{C} / \mathrm{N}$ & 93.8 & 90.9 & -69.5 & -111 \\
\hline \multirow[t]{6}{*}{ Soil physical properties } & Bulk density & 91.5 & 89 & 83.5 & 74.1 \\
\hline & Total porosity & 92.2 & 90.4 & 86.3 & 81.6 \\
\hline & Macroporosity & 78.1 & 71 & 73.1 & 66.6 \\
\hline & PR & 70.9 & 68.4 & 38.9 & 20.5 \\
\hline & Soil moisture & 95.6 & 93.7 & 90.9 & 63.1 \\
\hline & Aggregate stability & 72 & 71.1 & 42.8 & 34.3 \\
\hline \multirow[t]{11}{*}{ Soil chemical properties } & $\mathrm{pH}$ & 90.3 & 89.5 & 82.9 & 79.2 \\
\hline & EC & 79.4 & 76.5 & 64.7 & 55.9 \\
\hline & $\mathrm{C}$ & 79.1 & 78 & 62.7 & 46.6 \\
\hline & $\mathrm{N}$ & 57.1 & 55.1 & 32.7 & 18.4 \\
\hline & $\mathrm{C} / \mathrm{N}$ & 72.3 & 70.1 & 34.5 & -58.6 \\
\hline & C sequestration & 86.3 & 87.3 & 74.2 & 58.9 \\
\hline & $\mathrm{N}$ sequestration & 62.5 & 61.7 & 38.6 & 23.1 \\
\hline & Available P & 70 & 68.1 & 39.7 & 29.9 \\
\hline & Available K & 70 & 67.8 & 48.4 & 35.2 \\
\hline & Available Ca & 60.1 & 57.9 & 40.7 & 33.5 \\
\hline & Available Mg & 77.4 & 72.4 & 50.1 & 37.8 \\
\hline \multirow[t]{2}{*}{ Soil biological properties } & Earthworm abundance & 54.8 & 51.6 & 29 & 17.2 \\
\hline & Earthworm biomass & 51.4 & 48.3 & 27.2 & 16.2 \\
\hline
\end{tabular}

\subsection{Principal Component Analyses (PCA)}

Different litter treatments, untreated trail, and litter and soil physical, chemical, and biological properties are presented (Figure 2). PCA results demonstrating the relation between litter treatments 
and soil properties showed that first and second axes explained $88.85 \%$ and $8.52 \%$ of total variance, respectively (Figure 2). The B-H-M and B-H treatments were positively correlated with soil physical properties (e.g., silt $(\mathrm{r}=0.94)$, aggregate stability $(\mathrm{r}=0.98)$, clay $(\mathrm{r}=0.96))$, and chemical properties (e.g., $\mathrm{Mg}(\mathrm{r}=0.99), \mathrm{P}(\mathrm{r}=0.97)$, soil C $(\mathrm{r}=0.97), \mathrm{C}$ sequestration $(\mathrm{r}=0.95))$.

The $\mathrm{U}$ and $\mathrm{B}$ treatments were negatively correlated with certain soil physical properties (e.g., soil bulk density $(r=-0.98)$, penetration resistance $(r=-0.96)$, soil moisture $(r=-0.77)$, and sand $(\mathrm{r}=-0.91))$, and chemical properties (e.g., litter and soil $\mathrm{C} / \mathrm{N}$ ratio $(\mathrm{r}=-0.86$ and $\mathrm{r}=-0.94))$. The UND treatment was positively correlated with the litter properties (e.g., thickness $(\mathrm{r}=-0.84), \mathrm{C}(\mathrm{r}=-0.81)$, and $\mathrm{N}(\mathrm{r}=-0.96))$, soil biological properties (earthworm density $(\mathrm{r}=-0.94)$ and biomass $(\mathrm{r}=-0.92)$ ), physical properties (e.g., total porosity $(\mathrm{r}=-0.98)$, macroporosity $(\mathrm{r}=-0.89))$, and chemical properties (e.g., $\mathrm{pH}(\mathrm{r}=-0.98), \mathrm{EC}(\mathrm{r}=-0.97)$, soil $\mathrm{C}(\mathrm{r}=-0.98)$, soil $\mathrm{N}(\mathrm{r}=-0.97), \mathrm{K}(\mathrm{r}=-0.98), \mathrm{Ca}(\mathrm{r}=-0.96)$, $\mathrm{N}$ sequestration $(\mathrm{r}=-0.95))$.

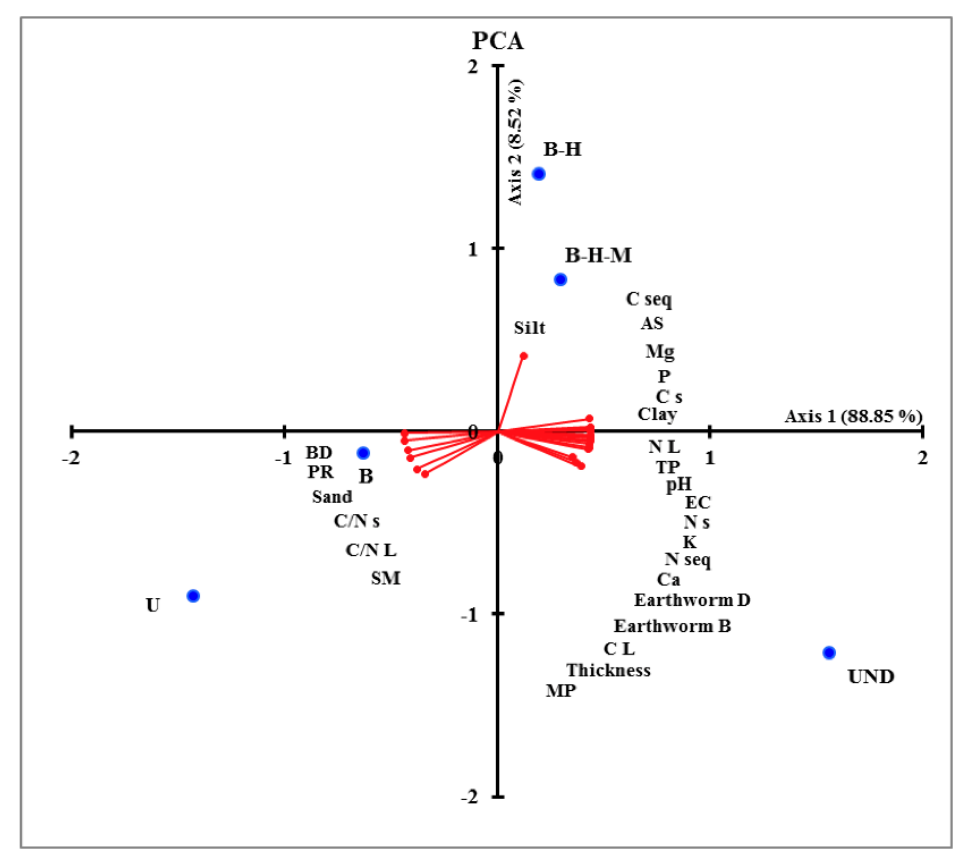

Figure 2. PCA ordination of the different litter species (Untreated trail (U), Undisturbed area (UND), Pure Beech (B), Beech-Hornbeam (B-H), Beech-Hornbeam-Maple (B-H-M)), and litter (Thickness, C, N, $\mathrm{C} / \mathrm{NL} ; \mathrm{C} / \mathrm{N}$ ratio of litter), and soil physical (BD; Bulk density, TP; Total porosity, MP; Macroporosity, PR; Penetration resistance, SM; Soil moisture, AS; Aggregate stability, Sand, Silt, Clay), chemical (pH, EC, C, N, C/NS; C/N ratio of soil, $\mathrm{C}$ seq; $\mathrm{C}$ sequestration, $\mathrm{N}$ seq; $\mathrm{N}$ sequestration, $\mathrm{P}, \mathrm{K}, \mathrm{Ca}, \mathrm{Mg}$ ), and biological (Earthworm D Earthworm density and Earthworm B; Earthworm biomass) properties.

\section{Discussion}

\subsection{Litter Properties}

Low-quality litter in the pure beech (B) treatment led to a lower $\mathrm{N}$ release than the B-H-M and B-H treatments. Similarly, Langenbruch et al. [45] found that the European beech litter showed a higher $\mathrm{C} / \mathrm{N}$ ratio and lignin/ $\mathrm{N}$ ratio, and lower $\mathrm{pH}$. In our study, litter of hornbeam and maple referred to as high quality litter, resulted in a decreased $\mathrm{C}$ and enhanced $\mathrm{C} / \mathrm{N}$ ratio. Consequently, the decomposition rate of litter and organic matter increased, and the accumulation of litter decreased on the soil surface at the B-H-M and B-H treatments. Though the litter layer characteristics significantly showed some evidence of recovery, our results are in line with previous studies that demonstrated that full recovery of litter layer required more than five years [19,45,48,59]. Mo et al. [60] found that the full recovery of soil organic matter content may need more than one or more decades after the cessation of litter 
removal. The highest litter accumulation was observed in the B treatment followed by B-H and B-H-M treatments. Previous studies demonstrated that the application of litter as mulch on the soil surface may affect soil temperature fluctuations, water exchange between soil and atmosphere, carbon and nutrient cycling, $\mathrm{pH}$, and cation exchange capacity $[19,29,30,32,33]$.

With the exception of the UND treatment, the highest litter and C accumulation was observed in the pure beech (B) plots. Our results agree with the previous findings, which concluded that litter quality is the most important factor affecting $C$ accumulation on the forest floor $[42,44-46,59]$. Since beech litter in the $\mathrm{B}$ treatment has high lignin and low $\mathrm{N}$, a higher $\mathrm{C} / \mathrm{N}$ ratio was measured, which ultimately led to lower decomposition rate [42,45,48,61].

Artificial disturbance (manipulation) of litter, especially in beech forest stands with humus form profiles (e.g., Amphi and Mor humus), can be effective to accelerate the decomposition process of litter, which resulted in a lower litter accumulation.

\subsection{Soil Physical Properties}

Results show that the soil bulk density improved following the litter treatments. However, the recovery values of soil bulk density in the B-H-M, B-H, and B treatments were still lower than the values recorded in the UND treatment, thus indicating that the full recovery of soil bulk density did not occur over the 5-year monitoring period. Natural recovery of soil physical properties (without restoration and rehabilitation treatments) is a slow process and may persist a long time compared to untrafficked areas $[5,35-39,41]$. Nevertheless, our results agree with the general observations that the addition of litter mulch on compacted surface soil may accelerate the restoration process and enhance the soil physical properties by improving the soil quality and stimulating biological activity [30-33,40].

Results indicate that with increasing silt content, the soil texture became lighter and with decreasing clay and sand contents, soil permeability and the number of pore spaces increased. With the augmentation of hornbeam and maple litter, soil physical properties were subjected to the improvement and recovery processes, however, full recovery of soil physical properties will require more than five years following litter treatments.

Results show that the full recovery of penetration resistance had not occurred following litter application. Nevertheless, protecting the soil surface with the hornbeam and maple species litter had the highest efficacy on the recovery of soil penetration resistance. The application of litter mulch on surface soil led to an increased surface roughness, enhanced soil aggregate stability, and decreased overland flows, which in turn resulted in an increased water infiltration rate [18,20,32]. As a consequence, through increased moisture availability, the litter decomposition rate improved following soil fauna and biological activities, thereby resulting in a loosening of soil and increasing the penetration resistance recovery rate.

Results also revealed that the recovery rate of soil physical properties was highest in the B-H-M, followed by B-H > B treatment, compared to the UND treatment. Over a 5-year period, soil aggregate stability recovered partially in the B-H-M, B-H, and B treatments; however, these recovery values were still lower in the litter treatments than in the UND treatment. External forces such as raindrop impact can break soil aggregates [62], the rate of which depends on the aggregate stability (erodibility) and the rainfall characteristics (erosivity). The studied soil was weakly aggregated and aggregate stability was relatively low, which is associated with lower levels of soil cementing agents such as clay and organic matter.

Results also showed that the lower level of soil physical recovery was related to the U treatment. Litter removal following ground-based skidding operations left the surface soil completely exposed, thereby increasing temperature fluctuations from/to soil surface, increasing raindrop impacts, decreasing water infiltration rate, all of which resulted in a striking increase on surface runoff and soil erosion [9,14]. This result confirms the findings of Vaezi et al. [62] who reported soil physical properties (aggregate size, bulk density and infiltration rate) were strongly damaged by raindrop 
impact as rainfall intensity increased. Raindrop impacts break soil aggregates at the soil surface, and small soil particles are released.

\subsection{Soil Chemical and Biological Properties}

By adding hornbeam litter in the B-H treatment, and also hornbeam and maple litter in the B-H-M treatment, soil chemical properties were partially able to recover. Our results indicate that two high-quality litter species (hornbeam and maple) were able to facilitate the recovery of soil organic matter and nutrients availability better than the low-quality litter (beech); these results are in line with the findings of previous studies [42,45-48].

The cation exchange capacity of soil is mostly dependent on soil $\mathrm{pH}$. As the soil $\mathrm{pH}$ increases, the cation exchange capacity such as $\mathrm{K}, \mathrm{Ca}$, and $\mathrm{Mg}$ in the soil also increases. One of the most important effects of $\mathrm{pH}$ was its influence on the extent and diversity of soil biological activities such as earthworms, and some micro-organisms showed little tolerance to soil $\mathrm{pH}$ [44]. Our results indicate that the addition of beech litter on surface soil resulted in a higher soil acidification and a decrease in $\mathrm{pH}$. Similarly, Guckland et al. [44] found that soil $\mathrm{pH}$ and cation exchange capacity were lower in pure beech stands than in mixed stands.

Results demonstrated that in the hornbeam and maple litter treatments, $\mathrm{N}$ and $\mathrm{K}$ were higher and instead, in the beech litter, the amount of $C$ and, consequently, the $C / N$ ratio were higher. In this respect, our results are in line with previous studies reporting that tree species by litter fall processes significantly influenced chemical characteristics of the upper soil layers [19,44,46,59].

In general, species such as maple and hornbeam are applied as soil amendments, because the litter of these species has a considerable amount of $\mathrm{N}$, which results in a lower $\mathrm{C} / \mathrm{N}$ ratio in litters, thus increasing the decomposition rate. In line with the current study, Cools et al. [47] concluded that tree species with higher lignin and lower $\mathrm{N}$ have a striking decomposing rate, which led to higher $\mathrm{C} / \mathrm{N}$ ratio on both litter layer and mineral soil.

Applying litter mulch on soil surface is the main source of organic matter and N, which is rapidly decomposed by biological activities. During this process, mineralization is formed along with the production of soluble or gaseous mineral elements and humification with stable and resistant compounds against the soil microbe's activity $[48,63]$. The degree and extent of mineralization and the produced humus type depend on the type and amount of chemical compounds present in the organic matter. In other words, the tree elements combination significantly influenced the amount of organic matter, especially $C$ and N. Our results were in line with the conclusion of Augusto et al. [42] in that the acceleration of organic matter mineralization and nitrification rate were both highly species-specific.

In contrast, beech litter had a low quality, high $\mathrm{C}$, lower nutrients and $\mathrm{N}$, which resulted in a slower decomposition rate. Consequently, soil acidification occurred and led to nutrient deficiency, decreased biological activities, and delayed the ecological restoration of compacted soil in the B litter treatment. Similarly, Ampoorter et al. [40] indicated that the achievement of different soil ecological restoration treatments mainly depends on the soil condition such as $\mathrm{pH}$, nutrient availability and moisture content.

Litter mulch application on surface soil resulted in an increase of organic matter content and enhanced the decomposition rate of organic matter, which significantly influences soil microbial communities and leads to increased soil respiration [63]. The higher earthworm biomass has a significant relationship by decreasing the $\mathrm{C} / \mathrm{N}$ ratio in organic layers, and increasing the organic matter decomposition rate and finer soil texture $[19,40]$. Results showed that the earthworm density and biomass were higher in the loamy textured soil than clayey and sandy soils, which can be explained with the high amount of nutrients and water, and the ability to perpetuate more material in soil.

After five years of litter treatment, the PCA results revealed that soil bulk density, penetration resistance, soil moisture, sand, litter, and soil $\mathrm{C} / \mathrm{N}$ ratio rigorously correlated with the $\mathrm{U}$ and $\mathrm{B}$ treatments in the left PCA. With the exception of silt, other studied variables on the right PCA have a high correlation with the undisturbed plots, which consists of beech, hornbeam, and maple litters. 
The two litter treatments of B-H-M and B-H, however, located on the right PCA, did not show a strong relationship between these two litter treatments and soil properties, and had a significant difference with the UND treatment on the right. Therefore, the UND treatment were located at the one end of the axis 1 (right) and the $U$ treatment plots located at the other end of the axis 1 (left).

We can conclude that by applying the tested litters of different tree species on compacted soil, the soil characteristics were significantly improved and restored at the B, B-H, and B-H-M treatments. Specifically, results brought to light that the highest recovery rate of soil chemical and biological properties were found in the B-H-M, followed by B-H > B treatment, compared to the UND treatment. Nevertheless, the soil properties following the B, B-H, and B-H-M treatments still have a significant difference with UND treatment, even after a 5-year period since machine impact. Additionally, among the litter treatments, the highest level of soil recovery was found on the B-H-M treatment followed by B-H treatment, while the lower recovery values of soil properties were observed on the B treatment. Previous studies demonstrated that the decomposition rate of litter was higher in the hornbeam and maple species than with beech species, which resulted in a faster decomposition of organic matter and mineralization rate in the hornbeam and maple litter [43,46].

There was a significant correlation between silt and the B-H-M and B-H treatments, which confirmed that the condition of soil aggregates and texture had improved over a 5-year period after soil compaction. By increasing the percentage of hornbeam and maple litter, the organic carbon and $\mathrm{C} / \mathrm{N}$ ratio decreased. In contrast, by increasing the percentage of beech litter, the organic carbon and $\mathrm{C} / \mathrm{N}$ ratio increased. The higher organic carbon and $\mathrm{C} / \mathrm{N}$ ratio on the soil surface demonstrated the higher accumulation of organic matter and the lower litter decomposition rates. Similarly, Cools et al. [47] found that $\mathrm{C} / \mathrm{N}$ ratio was higher in the litter layer than under depth of $0-10 \mathrm{~cm}$ mineral soil, which can be attributed to freshly fallen leaves and high-lignin materials. By increasing soil depth, the organic matter broke down due to microbial activities, which resulted in a decreased $\mathrm{C} / \mathrm{N}$ ratio. In line with our findings, several studies reported that the efficacy of tree species on $\mathrm{C} / \mathrm{N}$ ratio decreased with increasing soil depth $[43,45,47,48,64]$. However, one important issue that should be taken into account is the effects of canopy cover on flux and diversity of throughfall chemical characteristics, which may influence the results obtained [65].

This research recommends an ecological restoration to reclaim compacted forest soils in the Hyrcanian forest through the application of high-quality litter species. Litter mulching operations should be performed on trail segments immediately after soil disturbances (ground-based machine traffic) to attenuate the negative effects of litter layer removal on in the increased runoff and soil loss. One point that should be taken into consideration is the application of litter that has a high quality, particularly $\mathrm{N}$-fixing species, to accelerate the restoration processes on the soil's physical, chemical, and biological properties.

\section{Conclusions}

We examined the effects of tree species litter as mulch on compacted soil in the skid trails to assess the efficacy of the tree species litter (pure beech (Fagus orientalis) - B, beech-hornbeam (Carpinus betulus) - B-H, and beech-hornbeam-maple (Acer velutinum) - B-H-M) on the recovery of litter and soil physical, chemical, and biological properties, compared to untreated skid trail (U), and undisturbed area (UND) over a 5-year period in the Hyrcanian forests (Iran). Our results indicated that the highest litter thickness, $\mathrm{C}$, and $\mathrm{N}$ of litter were observed in the UND treatment, while, the litter $\mathrm{C} / \mathrm{N}$ ratios were highest in the $\mathrm{U}$ trail. The highest recovery of soil physical was observed on the B-H-M $\approx$ $\mathrm{B}-\mathrm{H}$ treatment followed by the $\mathrm{B}$ treatment. With the exception of soil $\mathrm{C} / \mathrm{N}$ ratio, the highest soil $\mathrm{pH}, \mathrm{EC}, \mathrm{C}, \mathrm{N}, \mathrm{C}$ sequestration, $\mathrm{N}$ sequestration, and available nutrients $(\mathrm{P}, \mathrm{K}, \mathrm{Ca}$, and $\mathrm{Mg}$ ) values were found on the UND treatment followed by B-H-M and B-H treatments, whereas the lowest of these values were detected on the $\mathrm{B}$ and $\mathrm{U}$ treatments. The earthworm density and biomass were significantly higher on the UND than under $\mathrm{B}-\mathrm{H}-\mathrm{M} \approx \mathrm{B}-\mathrm{H}>\mathrm{B}>\mathrm{U}$ treatments. Litter of hornbeam and maple is known as high-quality litter and resulted in a decreased $C$ and enhanced $C / N$ ratio. 
Consequently, the decomposition rate of litter and organic matter increased, and accumulation of litter decreased on the soil surface at the B-H-M and B-H treatments. Our results suggest that the addition of leaf litters resulted in significant recovery of the tested soil and litter properties, but that despite these improvements, full recovery of litter layer did not occur within the five-year monitoring period. Furthermore, recovery of forest soils following ground-based mechanized operations can naturally occur, albeit normally at a slower pace, with the presence of climatic processes and the activity of roots and soil fauna.

Author Contributions: M.J. and A.N. conceived and designed the experiments; M.J. and A.N. performed the experiments and analyzed the data; all authors wrote the paper.

Funding: This research was funded by the Deputy of Research, University of Tehran. The work was also supported by the German Research Foundation (DFG) and the Technical University of Munich (TUM) in the framework of the Open Access Publishing Program.

Acknowledgments: We would like to acknowledge the assistance of the field crew; Ghodrat Daneshvar from Kheyrud Forest Research Station, Nowshahr.

Conflicts of Interest: The authors declare no conflict of interest.

\section{References}

1. Grace, J.M.; Skaggs, R.W.; Cassel, D.K. Soil physical changes associated with forest harvesting operations on an organic soil. Soil Sci. Soc. Am. J. 2006, 70, 503-509. [CrossRef]

2. Labelle, E.R.; Jaeger, D. Soil compaction caused by cut-to-length forest operations and possible short-term natural rehabilitation of soil density. Soil Sci. Soc. Am. J. 2011, 75, 2314-2329. [CrossRef]

3. Jourgholami, M.; Soltanpour, S.; Etehadi Abari, M.; Zenner, E.K. Influence of slope on physical soil disturbance due to farm tractor forwarding in a Hyrcanian forest of northern Iran. iForest 2014, 7, 342-348. [CrossRef]

4. Rab, M.A. Recovery of soil physical properties from compaction and soil profile disturbance caused by logging of native forest in Victorian central highlands, Australia. For. Ecol. Manag. 2004, 191, 329-340. [CrossRef]

5. Cambi, M.; Certini, G.; Neri, F.; Marchi, E. The impact of heavy traffic on forest soils: A review. For. Ecol. Manag. 2015, 338, 124-138. [CrossRef]

6. Ampoorter, E.; Goris, R.; Cornelis, W.M.; Verheyen, K. Impact of mechanized logging on compaction status of sandy forest soils. For. Ecol. Manag. 2007, 241, 162-174. [CrossRef]

7. Epron, D.; Plain, C.; Ndiaye, F.-K.; Bonnaud, P.; Pasquier, C.; Ranger, J. Effects of compaction by heavy machine traffic on soil fluxes of methane and carbon dioxide in a temperate broadleaved forest. For. Ecol. Manag. 2016, 382, 1-9. [CrossRef]

8. Sosa-Pérez, G.; MacDonald, L.H. Reductions in road sediment production and road-stream connectivity from two decommissioning treatments. For. Ecol. Manag. 2017, 398, 116-129. [CrossRef]

9. Jourgholami, M.; Fathi, K.; Labelle, E.R. Effects of foliage and traffic intensity on runoff and sediment in skid trails after trafficking in a deciduous forest. Eur. J. For. Res. 2018, 137, 223-235. [CrossRef]

10. Poltorak, B.J.; Labelle, E.R.; Jaeger, D. Soil displacement during ground-based mechanized forest operations using mixed-wood brush mats. Soil Tillage Res. 2018, 179, 96-104. [CrossRef]

11. Stuart, G.W.; Edwards, P.J. Concepts about forests and water. North. J. Appl. For. 2006, 23, 11-19.

12. Jourgholami, M.; Labelle, E.R.; Feghhi, J. Response of runoff and sediment on skid trails of varying gradient and traffic intensity over a two-year period. Forests 2017, 8, 472. [CrossRef]

13. Dung, B.X.; Gomi, T.; Miyata, S.; Sidle, R.C.; Kosugi, K.; Onda, Y. Runoff responses to forest thinning at plot and catchment scales in a headwater catchment draining Japanese cypress forest. J. Hydrol. 2012, 444-445, 51-62. [CrossRef]

14. Malvar, M.C.; Silva, F.C.; Prats, S.A.; Vieira, D.C.S.; Coelho, C.O.A.; Keizer, J.J. Short-term effects of post-fire salvage logging on runoff and soil erosion. For. Ecol. Manag. 2017, 400, 555-567. [CrossRef]

15. Wagenbrenner, J.W.; MacDonald, L.H.; Coats, R.N.; Robichaud, P.R.; Brown, R.E. Effects of post-fire salvage logging and a skid trail treatment on ground cover, soils, and sediment production in the interior western United States. For. Ecol. Manag. 2015, 335, 176-193. [CrossRef] 
16. Cristan, R.; Aust, W.M.; Bolding, M.C.; Barrett, S.M.; Munsell, J.F.; Schilling, E. Effectiveness of forestry best management practices in the United States: Literature review. For. Ecol. Manag. 2016, 360, $133-151$. [CrossRef]

17. Etehadi Abari, M.; Majnounian, B.; Malekian, A.; Jourgholami, M. Effects of forest harvesting on runoff and sediment characteristics in the Hyrcanian forests, northern Iran. Eur. J. For. Res. 2017, 136, 375-386. [CrossRef]

18. Jourgholami, M.; Abari, M.E. Effectiveness of sawdust and straw mulching on postharvest runoff and soil erosion of a skid trail in a mixed forest. Ecol. Eng. 2017, 109, 1-9. [CrossRef]

19. Sayer, E.J. Using experimental manipulation to assess the roles of leaf litter in the functioning of forest ecosystems. Biol. Rev. 2006, 81, 1-31. [CrossRef] [PubMed]

20. Li, X.; Niu, J.; Xie, B. The effect of leaf litter cover on surface runoff and soil erosion in northern China. PLoS ONE 2014, 9, e107789. [CrossRef] [PubMed]

21. Dunkerley, D.L. Percolation through leaf litter: What happens during rainfall events of varying intensity? J. Hydrol. 2015, 525, 737-746. [CrossRef]

22. Thompson, A.; Davis, J.D.; Oliphant, A.J. Surface runoff and soil erosion under eucalyptus and oak canopy. Earth Surf. Proc. Land. 2016, 41, 1018-1026. [CrossRef]

23. Li, X.; Xiao, Q.; Niu, J.; Dymond, S.; McPherson, E.G.; van Doorn, N.; Yu, X.; Xie, B.; Zhang, K.; Li, J. Rainfall interception by tree crown and leaf litter: An interactive process. Hydrol. Process. 2017, 31, 3533-3542. [CrossRef]

24. Gerrits, A.M.J.; Pfister, L.; Savenije, H.H.G. Spatial and temporal variability of canopy and forest floor interception in a beech forest. Hydrol. Process. 2010, 24, 3011-3025. [CrossRef]

25. Wagenbrenner, J.W.; Robichaud, P.R.; Elliot, W.J. Rill erosion in natural and disturbed forests: 2. Modeling approaches. Water Resour. Res. 2010, 46, W10507. [CrossRef]

26. Wade, C.R.; Bolding, M.C.; Aust, W.M.; Lakel, W.A. Comparison of five erosion control techniques for bladed skid trails in Virginia. South. J. Appl. For. 2012, 36, 191-197. [CrossRef]

27. Prats, S.A.; Wagenbrenner, J.; Malvar, M.C.; Martins, M.A.S.; Keizer, J.J. Mid-term and scaling effects of forest residue mulching on post-fire runoff and soil erosion. Sci. Total Environ. 2016, 573, 1242-1254. [CrossRef] [PubMed]

28. Wear, L.R.; Aust, W.M.; Bolding, M.C.; Strahm, B.D.; Dolloff, C.A. Effectiveness of best management practices for sediment reduction at operational forest stream crossings. For. Ecol. Manag. 2013, 289, 551-561. [CrossRef]

29. Merlim, A.D.; Guerra, J.G.M.; Junqueira, R.M.; de Aquino, A.M. Soil macrofauna in cover crops of figs grown under organic management. Sci. Agric. 2005, 62, 57-61. [CrossRef]

30. Mulumba, L.N.; Lal, R. Mulching effects on selected soil physical properties. Soil Tillage Res. 2008, 98, 106-111. [CrossRef]

31. Smets, T.; Poesen, J.; Knapen, A. Spatial scale effects on the effectiveness of organic mulches in reducing soil erosion by water. Earth-Sci. Rev. 2008, 89, 1-12. [CrossRef]

32. Jordán, A.; Zavala, L.M.; Gil, J. Effects of mulching on soil physical properties and runoff under semi-arid conditions in southern Spain. CATENA 2010, 81, 77-85. [CrossRef]

33. Lombao, A.; Díaz-Raviña, M.; Martín, A.; Barreiro, A.; Fontúrbel, M.T.; Vega, J.A.; Fernández, C.; Carballas, T. Influence of straw mulch application on the properties of a soil affected by a forest wildfire. Span. J. Soil Sci. 2015, 5, 26-40.

34. Ojanen, P.; Mäkiranta, P.; Penttilä, T.; Minkkinen, K. Do logging residue piles trigger extra decomposition of soil organic matter? For. Ecol. Manag. 2017, 405, 367-380. [CrossRef]

35. Greacen, E.L.; Sands, R. Compaction of forest soils: A review. Aust. J. Soil Res. 1980, 18, 163-189. [CrossRef]

36. Croke, J.; Hairsine, P.; Fogarty, P. Soil recovery from track construction and harvesting changes in surface infiltration, erosion and delivery rates with time. For. Ecol. Manag. 2001, 143, 3-12. [CrossRef]

37. Bottinelli, N.; Hallaire, V.; Goutal, N.; Bonnaud, P.; Ranger, J. Impact of heavy traffic on soil macroporosity of two silty forest soils: Initial effect and short-term recovery. Geoderma 2014, 217-218, 10-17. [CrossRef]

38. Meyer, C.; Luscher, P.; Schulin, R. Recovery of forest soil from compaction in skid tracks planted with black alder (Alnus glutinosa (L.) Gaertn.). Soil Tillage Res. 2014, 143, 7-16. [CrossRef]

39. Ebeling, C.; Lang, F.; Gaertig, T. Structural recovery in three selected forest soils after compaction by forest machines in Lower Saxony, Germany. For. Ecol. Manag. 2016, 359, 74-82. [CrossRef] 
40. Ampoorter, E.; De Schrijver, A.; De Frenne, P.; Hermy, M.; Verheyen, K. Experimental assessment of ecological restoration options for compacted forest soils. Ecol. Eng. 2011, 37, 1734-1746. [CrossRef]

41. Ezzati, S.; Najafi, A.; Rab, M.A.; Zenner, E.K. Recovery of soil bulk density, porosity and rutting from ground skidding over a 20-year period after timber harvesting in Iran. Silva Fenn. 2012, 46, 521-538. [CrossRef]

42. Augusto, L.; Ranger, J.; Binkley, D.; Rothe, A. Impact of several common tree species of European temperate forests on soil fertility. Ann. For. Sci. 2002, 59, 233-253. [CrossRef]

43. Hagen-Thorn, A.; Callesen, I.; Armolaitis, K.; Nihlgard, B. The impact of six European tree species on the chemistry of mineral topsoil in forest plantations on former agricultural land. For. Ecol. Manag. 2004, 195, 373-384. [CrossRef]

44. Guckland, A.; Jacob, M.; Flessa, H.; Thomas, F.M.; Leuschner, C. Acidity, nutrient stocks, and organic-matter content in soils of a temperate deciduous forest with different abundance of European beech (Fagus sylvatica L.). J. Plant Nutr. Soil Sci. 2009, 172, 500-511. [CrossRef]

45. Langenbruch, C.; Helfrich, M.; Flessa, H. Effects of beech (Fagus sylvatica), ash (Fraxinus excelsior) and lime (Tilia spec.) on soil chemical properties in a mixed deciduous forest. Plant. Soil. 2012, 352, 389-403. [CrossRef]

46. Neirynck, J.; Mirtcheva, S.; Sioen, G.; Lust, N. Acer pseudoplatanus L., Quercus robur L. and Fagus sylvatica L. on earthworm biomass and physico-chemical properties of a loamy topsoil. For. Ecol. Manag. 2000, 133, 275-286. [CrossRef]

47. Cools, N.; Vesterdal, L.; De Vos, B.; Vanguelova, E.; Hansen, K. Tree species is the major factor explaining C:N ratios in European forest soils. For. Ecol. Manag. 2014, 311, 3-16. [CrossRef]

48. Marty, C.; Houle, D.; Gagnon, C.; Courchesne, F. The relationships of soil total nitrogen concentrations, pools and $\mathrm{C}: \mathrm{N}$ ratios with climate, vegetation types and nitrate deposition in temperate and boreal forests of eastern Canada. CATENA 2017, 152, 163-172. [CrossRef]

49. Sato, Y.; Kumagai, T.; Kume, A.; Otsuki, K.; Ogawa, S. Experimental analysis of moisture dynamics of litter layers-The effect of rainfall conditions and leaf shapes. Hydrol. Process. 2004, 18, 3007-3018. [CrossRef]

50. Geißler, C.; Kühn, P.; Böhnke, M.; Bruelheide, H.; Shi, X.; Scholten, T. Splash erosion potential under tree canopies in subtropical SE China. CATENA 2012, 91, 85-93. [CrossRef]

51. Li, X.; Niu, J.; Xie, B. Study on hydrological functions of litter layers in North China. PLoS ONE 2013, 8, e70328. [CrossRef] [PubMed]

52. Hattenschwiler, S.; Jørgensen, H.B. Carbon quality rather than stoichiometry controls litter decomposition in a tropical rain forest. J. Ecol. 2010, 98, 754-763. [CrossRef]

53. Gee, G.W.; Bauder, J.W. Particle-size analysis. In Methods of Soil Analysis. Part 1. Physical and Mineralogical Methods; Klute, A., Ed.; Soil Science Society of America: Madison, WI, USA, 1986; pp. 383-411.

54. Danielson, R.E.; Southerland, P.L. Methods of Soil Analysis. Part I. Physical and Mineralogical Methods, 2nd ed.; American Society of Agronomy, Inc.; Soil Science Society of America: Madison, WI, USA, 1986; pp. 443-460.

55. Kemper, W.D.; Rosenau, R.C. Aggregate stability and size distribution. In Methods of Soil Analysis. Part I Physical and Mineralogical Properties, 2nd ed.; Klute, A., Ed.; Agronomy Monograph; American Society of Agronomy, Inc.; Soil Science Society of America: Madison, WI, USA, 1986; Volume 9, pp. 425-442.

56. Walkley, A.; Black, I.A. An examination of the Degtjareff method for determining soil organic matter and a proposed modification of chromic acid titration method. Soil Sci. 1934, 37, 29-38. [CrossRef]

57. Salehi, A.; Ghorbanzadeh, N.; Kahneh, E. Earthworm biomass and abondance, soil chemical and physical properties under different poplar plantations in the north of Iran. J. For. Sci. 2013, 59, 223-229. [CrossRef]

58. Kooch, Y.; Zaccone, C.; Lamersdorf, N.P.; Tonon, G. Pit and mound influence on soil features in an Oriental Beech (Fagus orientalis Lipsky) forest. Eur. J. For. Res. 2014, 133, 347-354. [CrossRef]

59. Mareschal, L.; Bonnaud, P.; Turpault, M.P.; Ranger, J. Impact of common European tree species on the chemical and physicochemical properties of fine earth: An unusual pattern. Eur. J. Soil Sci. 2010, 61, 14-23. [CrossRef]

60. Mo, J.; Brown, S.; Peng, S.; Kong, G. Nitrogen availability in disturbed, rehabilitated and mature forests of tropical China. For. Ecol. Manag. 2003, 175, 573-583. [CrossRef]

61. Jacob, M.; Viedenz, K.; Polle, A.; Thomas, F.M. Leaf litter decomposition in temperate deciduous forest stands with a decreasing fraction of beech (Fagus sylvatica). Oecologia 2010, 164, 1083-1094. [CrossRef] [PubMed]

62. Vaezi, A.R.; Ahmadi, M.; Cerdà, A. Contribution of raindrop impact to the change of soil physical properties and water erosion under semi-arid rainfalls. Sci. Total Environ. 2017, 583, 382-392. [CrossRef] [PubMed] 
63. Prescott, C.E.; Grayston, S.J. Tree species influence on microbial communities in litter and soil: Current knowledge and research needs. For. Ecol. Manag. 2013, 309, 19-27. [CrossRef]

64. Hansson, K.; Olsson, B.A.; Olsson, M.; Johansson, U.; Kleja, D.B. Differences in soil properties in adjacent stands of Scots pine, Norway spruce and silver birch in SW Sweden. For. Ecol. Manag. 2011, 262, 522-530. [CrossRef]

65. Salehi, M.; Zahedi Amiri, G.; Attarod, P.; Salehi, A.; Brunner, I.; Schleppi, P.; Thimonier, A. Seasonal variations of throughfall chemistry in pure and mixed stands of Oriental beech (Fagus orientalis Lipsky) in Hyrcanian forests (Iran). Ann. For. Sci. 2016, 73, 371-380. [CrossRef] 